\title{
Mechanistic Insights into Gold Organometallic Compounds and their Biomedical Applications
}

\author{
Sophie Jürgens and Angela Casini*
}

\begin{abstract}
The application of gold in medicine can be traced back several thousand years and $\mathrm{Au}(\mathrm{I})$ compounds have been used in the treatment of rheumatoid arthritis since the last century. Recently research into gold-based drugs for a number of human diseases has seen a renaissance due to their markedly different modes of action with respect to the classical platinum chemotherapeutic compounds. Within this research area, organometallic gold complexes have been particularly explored, mainly due to their higher stability in physiological conditions guaranteed by the presence of a direct $\mathrm{Au}-\mathrm{C}$ bond. Thus, a number of compounds have been tested for their uses as anticancer, antibacterial, antiprotozoal as well as anti-HIV agents. In this review a selection of the main results obtained on the synthesis, chemical properties and biological activities of two of the most explored families of organometallics - $\mathrm{Au}(\mathrm{I}) \mathrm{N}$-heterocyclic carbenes (NHCs) and cyclometalated $\mathrm{Au}(\mathrm{III})$ compounds - are summarized. Their structure-activity relationships and modes of action at the cellular level are also discussed, which constitute the basis for future drug design.
\end{abstract}

Keywords: Biomedical applications · Gold organometallic compounds

\section{Introduction}

The discovery of the bacteriostatic properties of gold cyanide, $\mathrm{K}\left[\mathrm{Au}(\mathrm{CN})_{2}\right]$, by Robert Koch in 1890 against tubercle bacillus was the beginning of the use of goldbased compounds in modern medicine. In the belief that rheumatoid arthritis was an atypical form of tuberculosis, the use of gold(I) salts was also proposed for the treatment of this disease. By the early 1930s, gold therapy (chrysotherapy) was discontinued as a treatment of tuberculosis based on its ineffectiveness; however, it is still widely used for the management of rheumatoid arthritis.

In recent years, gold compounds have found clinical relevance as antirheumatic drugs in the form of auranofin ([triethylphosphine (2,3,4,6-tetra-Oacetyl- $\beta$-1-D-(thiopyranosato-S)Au(I)]), Ridaura $^{\mathrm{TM}}$ ), aurothioglucose (Solganol ${ }^{\mathrm{TM}}$ ) and aurothiomalate (Myochrisine $^{\mathrm{TM}}$ or Aurolate ${ }^{\mathrm{TM}}$ ) (Fig. 1). The success of the

${ }^{\star}$ Correspondence: Prof. A. Casini

School of Chemistry

Cardiff University

Park Place, CF10 3AT Cardiff, UK

E-mail: casinia@cardiff.ac.uk
platinum(II) complex cisplatin and derivatives in cancer chemotherapy stimulated interest in development of gold-based cytotoxic agents which has yielded extensive research into this field. Thus, the established antiarthritic drug auranofin was recently repurposed for its anticancer properties and is currently undergoing evaluation in three distinct US clinical trials. ${ }^{[1]}$ To a lesser extent, gold compounds have also been evaluated as antimicrobial, [2] anti-malarial ${ }^{[3]}$ and anti-HIV agents. ${ }^{[4]}$

Concerning Au(I) compounds, auranofin was initially found to be cytotoxic towards tumor cells in vitro, leading to the identification of other $\mathrm{Au}(\mathrm{I})$ phosphines with marked antitumor activity. ${ }^{[5]}$ Among the various examples, bis-chelated $\mathrm{Au}(\mathrm{I})$ diphosphine complexes of the type $\left.[\text { AuI (dppe })_{2}\right] \mathrm{Cl}$ (dppe $=$ bis (diphenylphosphino)ethane) were patented for therapeutic uses by Berners-Price et al. in 1986.[6] Despite their relatively good stability in physiological conditions, it was soon clear that more efforts should have been spent to modulate the reactivity of these $\mathrm{Au}(\mathrm{I})$ complexes for biomedical applications, including their selectivity to cancer cells.

$\mathrm{Au}(\mathrm{III})$ compounds as anticancer agents appeared to be a logical step forward from platinum(II)-based compounds, since gold(III) is isoelectronic $\left(\mathrm{d}^{8}\right)$ and isostructural to platinum(II) featuring the same square-planar geometry. However, numerous studies have shown that anticancer gold compounds target other biomolecules and biological pathways with respect to $\mathrm{Pt}(\mathrm{II})$ complexes. ${ }^{[7]} \mathrm{As}$ $\mathrm{Au}(\mathrm{III})$ is easily reduced to more stable $\mathrm{Au}(\mathrm{I}) / \mathrm{Au}(\mathrm{o})$ species, $\mathrm{Au}(\mathrm{III})$ complexes are generally strongly oxidizing agents. Reductions can be easily driven by thiol groups of biological systems, making $\mathrm{Au}(\mathrm{III})$ potentially toxic. ${ }^{[8]}$ Therefore, $\mathrm{Au}(\mathrm{III})$ complexes were long believed not to be suitable for medicinal applications.

In this context, organometallic chemistry offers a convenient way for the stabilization of the $\mathrm{Au}(\mathrm{I}) /(\mathrm{III})$ center and 'fine-tuning' of the complexes' physiochemical properties via the establishment of a direct metal-carbon bond. Thus, different families of

$$
\underbrace{\mathrm{OAC}}_{\text {OAc }} \mathrm{S}-\mathrm{Au}_{\mathrm{a}}-\mathrm{PEt}_{3}
$$

Fig. 1. Structures of $A u(I)$ anti-rheumatic drugs 
organometallic gold complexes, including $\mathrm{N}$-heterocyclic carbenes (NHCs) and cyclometallated compounds, have been explored for biological applications. Moreover, also alkynyl gold(I) complexes were designed and tested for their anticancer properties, although so far they are much less represented.[9] Very recently, Laguna and co-workers reported on the synthesis of complex $\left[\mathrm{Au}\left(\mathrm{C} \equiv \mathrm{CCH}_{2} \mathrm{Spy}\right.\right.$ ridine $)(\mathrm{PTA})](\mathrm{PTA}=1,3,5$-triaza-7-phosphaadamantane) which was tested for its anticancer activity in vitro and in vivo. ${ }^{[10]}$ When this derivative is administered by intraperitoneal injection in athymic nude mice inoculated with HTC-116-luc2 (colon cancer) cells, it prolongs their survival and displays moderate inhibition of the tumor growth with no subsequent organ damage after treatment.

Metal-NHC compounds have been widely used for catalysis due to their strong $\sigma$-donor properties, which, together with the strength of the metal-carbon bond, make such compounds resistant towards oxidation and endow them with overall high chemical and thermal stability. Some of these properties made the research on the biological potential of metal-NHC complexes one of the most active areas within the field of bioorganometallic chemistry. In the past few years, over 100 reports and more than 350 new transition metal complexes containing NHC ligands as potential antitumor metallodrugs could be counted. ${ }^{[11]}$

Concerning cyclometalated complexes, numerous ligand systems utilizing different donor atoms have been described that were able to stabilize the $\mathrm{Au}(\mathrm{III})$ center. $^{[12]}$ Cyclometalation reactions producing five-membered ring products are very favorable, being performed at room temperature with a variety of substrates, such as amines, imines, 2-phenylpyridines, benzo[ $h]$ quinones, other nitrogen donor ligands, oxygen-containing compounds, phosphorus and sulfur donors etc. Thus, a consistent number of reports includes these families of complexes. ${ }^{[13]}$

Here, we will include representative examples of the above-mentioned families of NHC and cyclometalated gold complexes, focusing on those displaying most promising biological effects including as anticancer agents, as well as antibacterial and antiviral compounds. We refer the reader to more extensive reviews for deeper insights into the field. ${ }^{[11,14]}$

\section{Gold(I) N-Heterocyclic Carbene Complexes}

$\mathrm{N}$-heterocyclic carbenes (NHCs) are defined as singlet-carbenes containing a divalent carbenic carbon with at least one nitrogen atom in the heterocycle. ${ }^{[13]}$
The development of stable metal NHC complexes has attracted increasing attention in research of metallopharmaceuticals. NHCs originated from the deprotonation of 1,3 di-substituted imidazolium salts, by appropriate external base, produce metal NHC complexes, stabilized through a 'push-pull' mechanism via synthetic routes with transmetalation being one of the most convenient, overcoming the difficulties of unstable free heterocyclic carbene isolation. Thus, the use of silver carbene complexes as carbene transfer reagents for the synthesis of other metal NHC complexes, including $\mathrm{Au}(\mathrm{I}) \mathrm{NHCs}$, is very common.

Below, we will provide an overview of the most representative $\mathrm{Au}(\mathrm{I}) \mathrm{NHC}$ scaffolds for different therapeutic applications and will summarize the knowledge on their respective proposed modes of action. Since their discovery as antiproliferative agents, various experiments on cancer cells revealed a variety of effects of $\mathrm{Au}(\mathrm{I}) \mathrm{NHCs}$ on cellular metabolism, including strong increase of ROS formation and reduced mitochondrial activity, finally resulting in apoptotic cell death. Notably, most of these effects could be attributed to the strong and selective inhibition of the seleno-enzyme thioredoxin reductase (TrxR) by $\mathrm{Au}(\mathrm{I})$ NHC complexes. ${ }^{[15]}$

Thioredoxin reductases (EC 1.8.1.9) are homodimeric flavoproteins catalyzing the NADPH-dependent reduction of thioredoxin (Trx), which is the major protein disulfide reductase in cells. ${ }^{[16]}$ TrxRs belong to the pyridine nucleotide-disulfide oxidoreductase family such as glutathione reductase, lipoamide dehydrogenase and trypanothione reductase. Thus, they form homodimers with each subunit featuring a redox-active disulfide bond and a bound FAD molecule.

Mammalian TrxRs possess a conserved -Cys-Val-Asn-Val-Gly-Cys- catalytic site, which is also found in human glutathione reductase (GR), located in the FAD-binding domain of the enzyme, and a NADPH binding site. Moreover, they contain a selenocysteine residue at the $\mathrm{C}$-terminal active site that is crucial for catalysis ${ }^{[17]}$ and that distinguishes them from GR or E. coli TrxR. [18] The redox active site is located on a flexible arm, solventexposed and reactive towards electrophilic agents, ${ }^{[19]}$ constituting an ideal target for the development of selective enzyme inhibitors, also based on gold, preferentially binding selenol groups. ${ }^{[20]}$ The thioredoxin system regulates crucial cell functions such as viability and proliferation. ${ }^{[21]}$ Interestingly, TrxR is able to reduce different protein substrates and low molecular weight molecules, in addition to the natural substrate thioredoxin. Both TrxR and Trx appear overexpressed in certain cancer types, ${ }^{[22]}$ leading to the assumption that the thioredoxin system exerts a crucial role in tumor onset and progression. In fact, both enzymes are considered as likely 'druggable' targets for anticancer treatment. ${ }^{[23]}$

\subsection{Anticancer Agents}

Due to the presence of NHC ligands, gold(I) NHC complexes show high stability in physiological conditions and ease of derivatization, allowing adjustment of their physicochemical properties. A first study by Berners-Price et al. appeared in 2006, where the synthesis, characterization and antimitochondrial activity of a family of cationic, linear two-coordinate $\left[\left(\mathrm{R}_{2} \mathrm{Im}\right)_{2} \mathrm{Au}\right]^{+} \quad(\mathrm{Im}=$ dialkylimidazol-2-ylidene) complexes of monodentate dialkylimidazol-2-ylidene ligands were reported, where the compounds' lipophilicity was fine-tuned by variation of the substituents $(R)$ on the imidazolium salt precursor.[24] The results show correlation between the hydrophilic/ lipophilic properties of the complexes and their ability to cause mitochondrial membrane permeabilization in isolated rat liver mitochondria.

The $\left[\left(\mathrm{R}_{2} \mathrm{Im}\right)_{2} \mathrm{Au}\right]^{+}$complexes were synthesized by reacting $\left(\mathrm{Me}_{2} \mathrm{~S}\right) \mathrm{AuCl}$ with excess of the appropriate imidazol2-ylidene, prepared in situ by deprotonation of the imidazolium salt with lithium bis(trimethylsilyl)amide (LiHMDS) in DMF at room temperature (Scheme 1). Of note, to influence the lipophilicity of the resulting Au-NHC complexes, the alkyl groups of the imidazolium salt were systematically varied.

Compounds $\mathbf{1} \cdot \mathbf{B r}$ and $\mathbf{3}-\mathbf{6} \cdot \mathbf{C l}$ induced dose-dependent ( $\mu \mathrm{M}$ range), $\mathrm{Ca}^{2+}$-sensitive mitochondrial swelling, with the most lipophilic compounds being the most active. Cyclosporin A, the benchmark inhibitor of the mitochondrial permeability transition pore, completely quenched the swelling induced by the gold complexes.

More recently, Ott and co-workers reported the $\mathrm{Au}(\mathrm{I})$ complex 7 (Fig. 2), based on an aminotriazole NHC ligand, via the $\mathrm{Ag}(\mathrm{I})$ oxide route. ${ }^{[25]}$ Interestingly, the complex triggered cytotoxic effects in HT-29 and MDA-MB-231 cancer cells, and showed an effective and fast cellular accumulation. As other bis-NHCs, the compound showed only moderate inhibition of TrxR $\left(\mathrm{IC}_{50}=1.2 \mu \mathrm{M}\right)$, in line with the idea that ligand exchange reactions at the $\mathrm{Au}(\mathrm{I})$ center should occur to allow direct binding to the protein's active site.

Gandin, Marzano and co-workers also developed the $\mathrm{Au}(\mathrm{I})$ 1,2,4-triazole based NHC complex 8 (Fig. 2) and assessed its cytotoxic properties in various human cancer cell lines, including cisplatinsensitive and -resistant cells. ${ }^{[26]}$ This monoNHC Au(I) complex was less effective than cisplatin and the corresponding $\mathrm{Ag}(\mathrm{I})$ - 


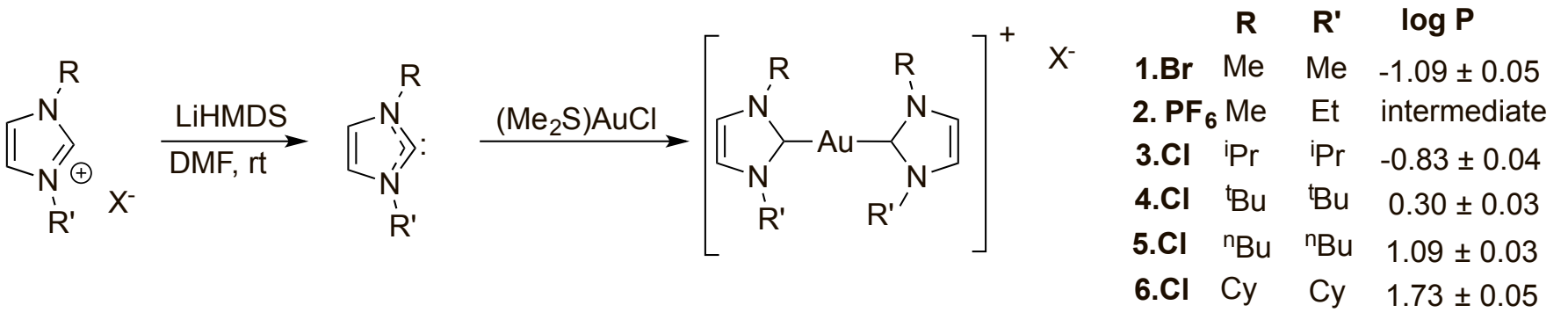

Scheme 1. Synthesis of Au(I) NHC complexes as reported in ref [24].

NHC and $\mathrm{Cu}(\mathrm{I})-\mathrm{NHC}$ complexes against all tested cancer cell lines. In agreement with previous findings, TrxR was potently inhibited by 8 , with $\mathrm{IC}_{50}$ values in the $\mathrm{nM}$ range after $15 \mathrm{~min}$ of incubation.

Gold NHC complexes have recently been explored for their interactions with non-canonical nucleic acid structures. Within this framework, Casini et al. reported on a series of caffeine-based $\mathrm{Au}(\mathrm{I})-\mathrm{NHC}$ complexes (9a-h, Fig. 2) bearing the methylated caffeine-2-ylidene ligand. The N7-substituted theophylline analogues have been synthesized and tested for antiproliferative activities in different cancerous and non-tumorigenic cell lines in comparison to 1,3-dimethylbenzimi dazol-2-ylidene derivatives. ${ }^{[26]}$ Complex 9b was almost two-fold more potent than cisplatin against A2780/R cells with low toxicity in non-cancerous HEK cells $\left(\mathrm{IC}_{50}>100 \mu \mathrm{M}\right)$. Notably, the compound was revealed to be scarcely toxic, also in healthy tissues ex vivo. Interestingly, further mechanistic studies showed that the highly selective antiproliferative properties of $9 \mathbf{b}$ may be due to efficient and selective DNA G-quadruplex-binding. Of note, molecules that template the formation or stabilize the structure of G-quadruplex DNA (G4) might lead to development of new effective anticancer drugs based on selective telomerase inhibition. Concerning other possible target proteins, the reported studies showed that $\mathbf{9 b}$ is only a modest PARP-1 inhibitor (i.e. a poor DDR impairing agent). ${ }_{[27]}$

Further X-ray diffraction studies on the adduct of the bis-carbene cationic complex $\left[\mathrm{Au}(9 \text {-methylcaffein-8-ylidene })_{2}\right]^{+}$9b with a model of DNA G-quadruplex (G4, Tel 23 sequence (5'-TAGGG(TTAGGG)3-3')) showed that the compound is able to bind the G4 at two distinct sites. In detail, the gold compound showed possible binding at the 3'-3' (3'end-3'end) site, as well as at the 5 '-5' (5'end-5'end) site. ${ }^{[28]}$ The two binding domains, located in the $3^{\prime}-3^{\prime}$ and $5^{\prime}-5$ ' sites, host either one or two [Au(9-methylcaffein8-ylidene) $\left.{ }_{2}\right]^{+}$molecules, respectively (Fig. 3). It is worth noting that this bis-carbene $\mathrm{Au}(\mathrm{I})$ complex is an ideal G4 stabilizer being: $i$ ) planar, ii) prone to electrostatic interactions with negatively charged DNA due to its overall positive charge, and iii) having two caffeine ligands (guanine analogues) able to associate to guanine moieties in G4 via $\pi$-stacking interactions.

Following the success of the trinuclear $\mathrm{Pt}(\mathrm{II})$ compound BBR3464 in clinical trials, ${ }^{[29]}$ the concept of multinuclearity has also been envisaged with $\mathrm{Au}(\mathrm{I})$ and $\mathrm{Au}(\mathrm{III})$-based organometallic compounds. In most cases, the polynuclear compounds

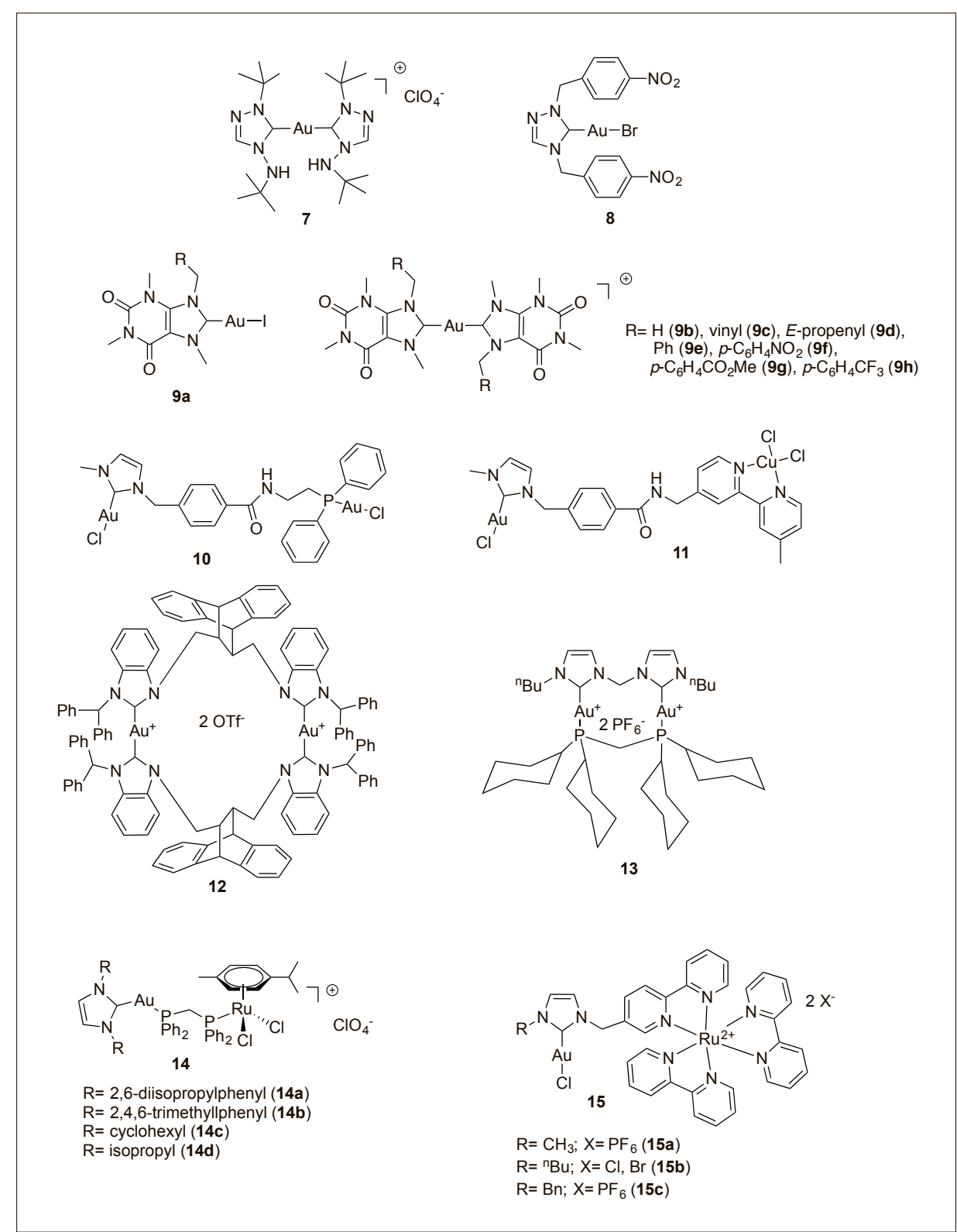

Fig. 2. Structure of anticancer $\mathrm{Au}(1) \mathrm{NHC}$ complexes. 
Fig. 3. Propeller organization of the Tel 23 sequence in the Tel 23:

[Au(9-methylcaffein8 -ylidene) $\left.)_{2}\right]^{+}$adduct ${ }^{[28]}$ (PDB accession code $5 \mathrm{CCW})$.

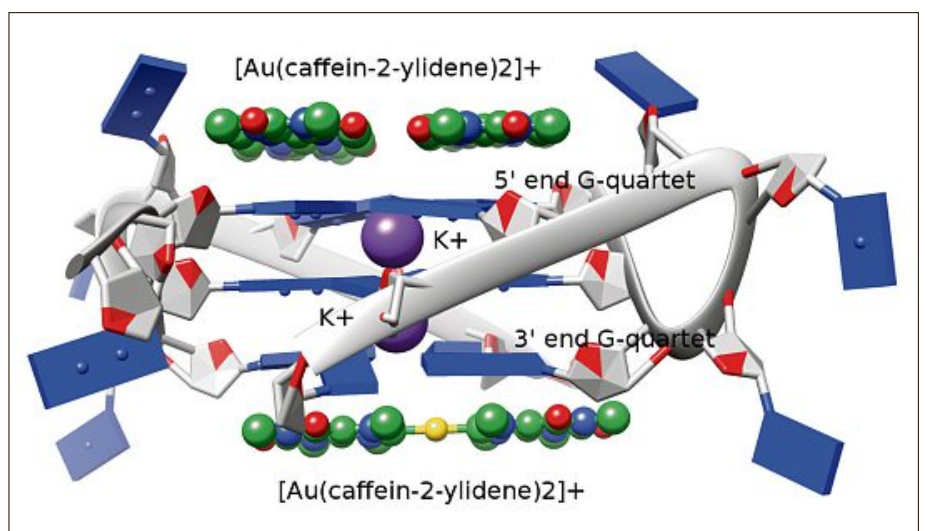

were shown to be potent inhibitors of cancer cell proliferation with a significant improvement compared with their mononuclear parent complexes.

As an example, Le Gendre and coworkers recently prepared and structurally characterized five neutral or cationic $\mathrm{Au}(\mathrm{I})$ NHC complexes via different methods. [30] Interestingly, some of them bear a pentafluorophenolic ester group as a possible 'activable' moiety for further functionalization. This group allowed an alkyl amine ligand or other $\mathrm{Au}(\mathrm{I})$-phosphine complex (10, Fig. 2) to be tethered via microwave activation. The obtained compounds have shown promising antiproliferative effects in human ovarian cancer A2780 cells, with respect to non-tumorigenic ones (HEK293T). In addition, the same authors also synthesized some homo- and hetero-bimetallic complexes $(\mathrm{Au}(\mathrm{I}) / \mathrm{Au}(\mathrm{I})$ or $\mathrm{Au}(\mathrm{I}) /$ $\mathrm{Cu}(\mathrm{II}), \mathrm{Au}(\mathrm{I}) / \mathrm{Ru}(\mathrm{II})$, respectively) based on the $\mathrm{Au}(\mathrm{I})-\mathrm{NHC}$ scaffold carrying a pentafluorophenol ester moiety and another $\mathrm{Au}(\mathrm{I})$ phosphane complex or a bipyridine ligand bearing a pendant amine function (e.g. 11, Fig. 2).[31] These complexes showed moderate anti-cancer properties against A2780, SKOV-3 and A549 cancer cell lines, with the $\mathrm{Au}-\mathrm{Cu}$ complex $\mathbf{1 1}$ being among the most active derivatives. Some compounds in this series were potent TrxR inhibitors in the nanomolar range in vitro and appeared to be toxic against healthy liver tissue at concentrations in the low micromolar range ex vivo.

Due to the high activity of the $\mathrm{Au}(\mathrm{I})$ bisNHC complexes and the fact that no chiral Au(I)-NHC complexes had been tested, Veige, Tan and co-workers developed the eighteen-membered chiral macrocyclic dicarbene-di-Au complex $\left[(\mu \text {-diNHC) } \mathrm{Au}(\mathrm{I})]_{2}[\mathrm{OTF}]_{2} 12\right.$ (Fig. 2). ${ }^{[32]}$ Interestingly, the enantiopure isomers of the ligand precursor provide access to the enantiopure versions of the binuclear $\mathrm{Au}(\mathrm{I})$ metallamacrocycles. Both isomers of $\mathbf{1 2}$ were characterized via different methods and displayed moderately cytotoxic to both healthy and cancerous lines without marked selectivity. Moreover, $\mathbf{1 2}$ is capable of penetrating the cell membrane already after few hours incubation, as shown by confocal microscopy, and causes cell death via apoptosis, as evidenced by DNA gel electrophoresis. ${ }^{[32]}$

In 2014, Che et al. developed a binuclear $\mathrm{Au}(\mathrm{I})$ complex (13, Fig. 2) containing mixed diphosphine and bis(NHC) bridging ligands.[33] The compound showed a favorable stability that guarantees efficient TrxR inhibition, while preventing inactivation by blood thiols. In addition, $\mathbf{1 3}$ demonstrated in vitro cytotoxic activity towards a panel of human cancer cells, including HeLa, MCF-7 (breast adenocarcinoma), SUNE1 (nasopharyngeal carcinoma), H1975 (lung adenocarcinoma), and B16F10 (mouse melanoma) cells, with $\mathrm{IC}_{50}$ values up to 13.5-fold lower than those of cisplatin. Complex 13 also inhibited HeLa cell sphere formation in vitro which is an indication of the cytotoxic effects of the compound in cancer stem cell populations, and inhibited angiogenesis in tumor models in vivo (reduction of blood microvessels in the tumor tissue of mice bearing $\mathrm{HeLa}$ xenografts).[33] Besides, the complex significantly reduced tumor growth in vivo, in mice bearing HeLa xenograft as well as highly aggressive mouse B16F10 melanoma without causing mouse death or body weight loss. Furthermore, it did not show systemic anaphylaxis on guinea pigs and did not induce localized irritation on rabbits in toxicology studies.

Interestingly, within the scope of achieving heteronuclear cytotoxic organometallics, in 2016 Contel et al. described a simple and efficient synthetic method to obtain $\mathrm{Au}(\mathrm{I})-\mathrm{NHCs}$ featuring a second ancillary ligand (such as phosphanes, phosphites, arsines and amines) starting from the chlorido precursor by abstraction of the chloride with silver perchlorate, and subsequent addition of the ancillary ligand. ${ }^{[34]}$ This synthetic strategy has been successfully applied in the preparation of a family of cationic heterobimetallic $\mathrm{Au}(\mathrm{I})$
Ru(II) complexes (14a-d, Fig. 2). Of note, the new heterometallic compounds are soluble in $\mathrm{DMSO} / \mathrm{H}_{2} \mathrm{O}, \mathrm{DMSO} / \mathrm{PBS}$ or $\mathrm{DMSO} /$ medium (1:99) mixtures at micromolar concentrations, relevant for biological testing. The bimetallic complexes showed a synergistic effect and exhibited higher cytotoxicities than their monometallic counterparts against renal cancer Caki-1 and colon cancer HCT-116 cell lines. Importantly, 14a-d are considerably less toxic to the nontumorigenic human embryonic kidney cell line (HEK-293T) than cisplatin. In addition, no interaction between the heterobimetallic complexes and plasmid (pBR322) DNA was observed and complex 14a was more efficient than the monometallic complex for the inhibition of TrxR in cancer cell extracts. ${ }^{\text {[34] }}$

Gornitzka and co-workers reported on the synthesis of three $\mathrm{Au}(\mathrm{I})-\mathrm{Ru}(\mathrm{II})$ heterobimetallic complexes $(\mathbf{1 5 a} \mathbf{a}-\mathbf{c}$, Fig. 2) combining an $\mathrm{Au}(\mathrm{I})-\mathrm{NHC}$ unit and a $\mathrm{Ru}$ (bipy), building block. ${ }^{[35]}$ The compounds have been fully characterized and evaluated for in vitro cytotoxic, antileishmanial, and antimalarial activities. The complexes were designed considering the photophysical properties of the $\mathrm{Ru}$ polypyridyl moiety, and the known anticancer activities of both metallic units. Interestingly, even though all the complexes show characteristics very similar to those of Ru(bipy) $)_{3}$ concerning luminescence properties, it should be noted that the luminescence quantum yield in water increases by about $30 \%$ in going from the mono-ruthenium complex $\left(\varphi_{\mathrm{em}}=\right.$ $0.020)$ to the corresponding $\mathrm{Au}(\mathrm{I})-\mathrm{Ru}$ (II) complex 15b $\left(\varphi_{\mathrm{em}}=0.026^{[35]}\right)$. Moreover, the emission maximum of the ruthenium precursor $(630 \mathrm{~nm})$ is slightly red-shifted in comparison with that of $\mathbf{1 5} \mathbf{b}(615 \mathrm{~nm})$. This shift could be due to solvatochromic effects, as a charged imidazolium unit in the mononuclear Ru(II) complex is changed to a neutral carbene unit in the $\mathrm{Au}(\mathrm{I})-\mathrm{Ru}(\mathrm{II})$ derivative. Furthermore, an $\mathrm{Au}(\mathrm{I})$-chlorido moiety is coordinated by the carbene, also leading to strong changes in the molecule.

Complexes 15a-c showed moderate anticancer properties very similar to those of $\mathrm{Ru}$ (bipy) ${ }_{3}$ in human hepatocellular carcinoma (Hep3B) cells, as well as modest activities $\left(\mathrm{IC}_{50}>10 \mu \mathrm{M}\right)$ against P. falciparum FcB1-Colombia strain. ${ }^{[35]}$ Further biological studies showed that the cytotoxic effects in tumor cells probably did not result via a DNA-related or an antimitochondrial mechanism. Moreover, the difference of $20 \mathrm{~nm}$ between the emission spectra of the $\mathrm{Au}(\mathrm{I})-\mathrm{Ru}(\mathrm{II})$ and $\mathrm{Ru}$ (II) complexes allowed their uptake in cancer cells to be followed via fluorescence microscopy. The obtained results suggested that $\mathrm{Au}(\mathrm{I})-\mathrm{Ru}(\mathrm{II})$ complexes are slowly 
transformed into the corresponding $\mathrm{Ru}$ complexes by release of Au cations to the cells, leading to cell death.

As a most recent example of heteronuclear $\mathrm{Au}(\mathrm{I})-\mathrm{Fe}(\mathrm{II})$ derivatives, four $\mathrm{Au}(\mathrm{I})-\mathrm{NHC}$ complexes featuring 4-ferrocenyl-substituted imidazol-2-ylidene ligands were investigated for antiproliferative and antivascular properties. ${ }^{[36]}$ The compounds were active against a panel of seven cancer cell lines, including multidrug-resistant ones, with low micromolar or nanomolar $\mathrm{IC}_{50}(72 \mathrm{~h})$ values, according to their lipophilicity and cellular uptake. Within this series, the two delocalized lipophilic cationic mono- and biscarbene complexes acted by increasing the reactive oxygen species in two ways: via a genuine ferrocene effect and by inhibiting the thioredoxin reductase. ${ }^{[36]}$ Both complexes gave rise to a reorganization of the F-actin cytoskeleton in endothelial and melanoma cells, associated with a G1 phase cell cycle arrest and a retarded cell migration. They proved antiangiogenic in tube formation assays with endothelial cells and vasculardisruptive on real blood vessels in the chorioallantoic membrane of chicken eggs. ${ }^{[36]}$ The cationic biscarbene complex was also tolerated well by mice where it led to a volume reduction of xenograft tumors (highly metastatic B16-F10 mouse melanoma cells) by up to $80 \%$.

\subsection{Antibacterial Agents}

Concerning possible applications as antibacterial agents, the Youngs research group was the first to introduce $\mathrm{NHCs}$ as carrier ligands for $\mathrm{Ag}^{+}$in 2004 for antibacterial applications. However, over the years, much less attention has been paid to the development of other metalNHC complexes as antibacterial agents in comparison to silver complexes. ${ }^{[37]}$ In the same year, Cetinkaya et al. studied the antibacterial activity of six cationic $\mathrm{Au}(\mathrm{I}) \mathrm{NHC}$ complexes, ${ }^{[38]}$ which included compounds 16, 17 and 18 (Fig. 4), displaying promising antibacterial activity in vitro against a series of bacterial strains (minimum inhibitory concentrations, MIC, in the range $3.1-6.3 \mu \mathrm{g} \mathrm{mL}^{-1}$ ). Remarkably,

Fig. 4. Structures of potent $\mathrm{Au}(1)$ and $\mathrm{Ag}(1)$ $\mathrm{NHC}$ complexes. the compounds' activity appeared to be strongly determined by the type of functional groups bound to the carrier ligands.

Afterwards, Ghosh et al. synthesized the compound [[1-benzyl-3-tert-butylimidazol-2-ylidene]AuCl] (20, Fig. 4) which inhibits the growth of Gram positive B. subtilis at a MIC of $15 \pm 2.3 \mu \mathrm{M}^{[39]}$ Interestingly, $\mathbf{2 0}$ is $c a$. two times more potent than its $\operatorname{Ag}(\mathrm{I})$ analogue 19 (Fig. 4). To unravel the mechanism of antimicrobial activity of 20, the morphology of the Bac. subtilis cells was studied following $4 \mathrm{~h}$ incubation with $4 \mu \mathrm{M}$ of $\mathbf{2 0}$. The elongation of the Bac. subtilis cells grown in the presence of $\mathbf{2 0}$ was observed compared with the control cells, suggesting that the compound inhibits bacterial proliferation by blocking the cytokinesis step of cell division. More recently, other $\mathrm{Au}(\mathrm{I}) \mathrm{NHC}$ complexes with different $\mathrm{N}$-substituents on the benzimidazole and bis(iminoacenaphthene) scaffolds showed only weak antibacterial activity. ${ }^{[40]}$

In 2012, Dinda et al. reported on the antibacterial activity of pyrazine functionalized pincer NHC-Ag(I) and $\mathrm{NHC}-\mathrm{Au}(\mathrm{I})$ complexes against antibioticresistant human pathogens of both Grampositive and Gram-negative bacteria, including their inhibitory effects on biofilm formation. ${ }^{[41]}$ In this study, complete synthetic and structural studies of $\mathrm{Au}(\mathrm{I})$ and $\operatorname{Ag}(\mathrm{I})$ complexes of 2-(1-methylimidazolium)pyrimidinechloride, 2,6-bis (1-methylimidazol)pyrazinechloride and 2,6-bis(1-methyl imidazol)pyrazinehexafluorophosphate were reported. Among them, the [chloro[2,6-bis(1-methylimidazol)pyrazine]Ag(I)], 21 and [chloro[2,6bis(1-methylimidazol)pyrazine]Au(I)], 22 complexes (Fig. 5) were observed to possess potent antimicrobial activity compared to several conventionally used antibiotics. ${ }^{[41]}$ Biofilm formation by Grampositive bacteria (Streptococcus mutans) and Gram-negative bacteria (E. coli) was also inhibited by $\mathbf{2 1}$ and $\mathbf{2 2}$ causing drastic damage to the bacterial cell wall and increasing membrane permeability. In addition, both compounds strongly bind to both Lys and Dap-Type peptidoglycan

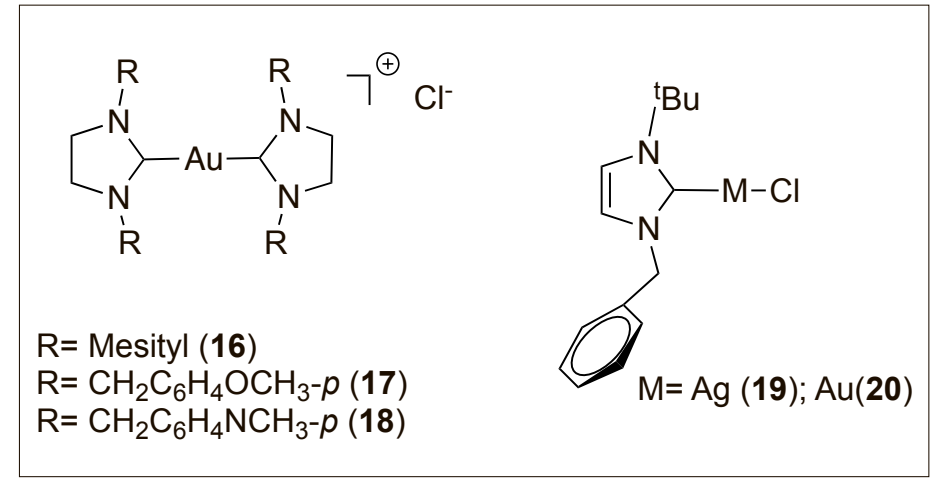

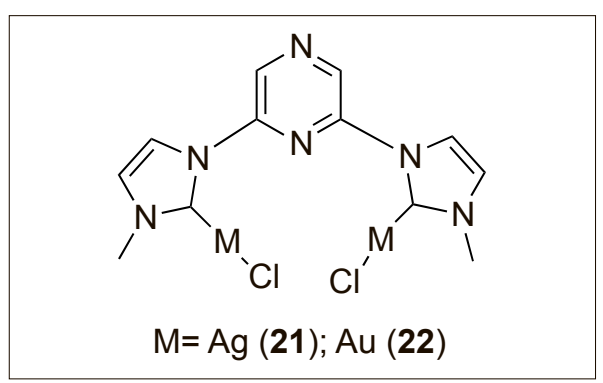

Fig. 5. Structures of dinuclear $\mathrm{Au}(1)$ and $\mathrm{Ag}(\mathrm{I})$ $\mathrm{NHC}$ complexes active as antibacterial agents.

layers, most likely inducing the observed damage of the bacterial cell wall.

Very recently, Ott and co-workers explored a new series of halogenated mono-NHC $\mathrm{Au}(\mathrm{I})$ complexes of general formula $\mathrm{NHC}-\mathrm{Au}(\mathrm{I})-\mathrm{Cl} .{ }^{[42]}$ The compounds showed promising activities in cancer cells, and the effective inhibition of mammalian and bacterial thioredoxin reductases was confirmed for all the reported derivatives. Interestingly, the determination of antibacterial effects against a panel of Gram-negative and Gram-positive strains demonstrated that all gold complexes displayed a high activity (low micromolar range) towards the Gram-positive bacteria, but they were substantially less active against the Gram-negative ones. ${ }^{[42]}$ Such a clear and consistent selectivity for Gram-positive strains has not been reported for previously investigated gold-NHC complexes. Whereas some complexes of the type $\mathrm{NHC}-\mathrm{Au}(\mathrm{I})-\mathrm{Cl}$ had indeed triggered much stronger effects in Gram-positive bacteria, ${ }^{[40 a]}$ this was not the case for other structural derivatives like cationic biscarbene derivatives. ${ }^{[38 \mathrm{~b}]}$

\subsection{Antimalarial Agents}

Malaria is an infectious disease caused by protozoan parasites of the genus Plasmodium and is still a major cause of illness and death in tropical countries. ${ }^{[43]}$ Among the species that cause malaria ( $P$. falciparum, $P$. vivax, $P$. ovale, $P$. malariae and $P$. knowlesi) $P$. falciparum causes the most serious form of the disease. Malaria parasites are transmitted by the bite of an infected female mosquito of the Anopheles genus. Although numerous advances have been made in the treatment of this disease, about 3.2 billion people - nearly half the world's population - remain at risk of malaria. In 2015 alone, there were 214 million new cases of the disease and more than 400,000 malaria-related deaths. ${ }^{[44]}$ Unfortunately, millions of people are still not accessing the health services necessary to prevent and treat this widespread disease.

In the treatment of malaria, several organic compounds have been successfully applied. As an example chloroquine (CQ) 
is among the most widely used antimalarial drug. However, due to the emergence and spread of CQ-resistant Plasmodium parasites, the efficacy of CQ has greatly diminished. In this context, to obtain improved drugs able to overcome CQ resistance, numerous metal complexes, including gold(I) and gold(III) compounds, have been designed as potential antimalarial agents. ${ }^{[43,45]}$

Among the organometallics with antimalarial properties, the $\mathrm{Au}(\mathrm{I})$ complex featuring the ylideneamine functionalized heterocyclic ligand- $\left[\mathrm{Au}\left(\mathrm{NO}_{3}\right)\left(1,3-{ }^{\mathrm{t}} \mathrm{BuIm}\right.\right.$ 2-ylidene)] - was found to be much less active than CQ against the 3D7 $P$. Falciparum strain.[46] Similarly, among the series of dinuclear $\mathrm{Au}(\mathrm{I})$ complexes containing bis-NHC ligands, only complex 23 (Fig. 6) manifested moderate antiplasmodial activity ( $\mathrm{IC}_{50} c a .15 \mu \mathrm{M}$ ) against the CQ-resistant $P$. falciparum strain FcM29-Cameroon, but was considerably less effective than CQ $\left(\mathrm{IC}_{50}=\right.$ $\left.0.445 \mu \mathrm{M}^{[47]}\right)$. Other bis-carbene gold(I) complexes in this series showed no activity $\left(\mathrm{IC}_{50}>39 \mu \mathrm{M}\right)$. Conversely, mononuclear gold(I) complexes containing nitrogen heterocyclic functionalized arms, namely quinoline (24) and bipyridine (25) moieties (Fig. 6) displayed significantly enhanced antiplasmodial activity $\left(\mathrm{IC}_{50}\right.$ values of 1.1 and $0.33 \mu \mathrm{M}$, respectively).. ${ }^{[4]}$
Interestingly, in the same study, two gold(III) complexes $\mathbf{2 6}$ and $\mathbf{2 7}$ with coordinated bis-NHC ligands (Fig. 6) showed only moderate activity against $P$. falciparum strain FcM29 ( IC $_{50}$ values of 9 and $13 \mu \mathrm{M}$, respectively). ${ }^{[47]}$

\section{Cyclometalated Gold(III) Complexes}

Cyclometalation is a convenient method of stabilizing metals in different oxidation states. This is particularly useful in the case of $\mathrm{Au}(\mathrm{III})$ compounds which are otherwise prone to be reduced to their respective $\mathrm{Au}(\mathrm{I})$ species as well as to colloidal gold. In general, cyclometalation is defined as the metal mediated $\mathrm{C}-\mathrm{R}$ bond activation of a cyclic organic ligand system. The chelating ring consists of a strong, covalent $\mathrm{C}-\mathrm{M} \sigma$ bond and a coordination $\mathrm{D}-\mathrm{M}$ bond $(\mathrm{D}=$ donor atom). These ligands incorporate one or more donor atoms (such as O-, N-, P-, $\mathrm{S}$ - or Se). However, it is worth mentioning that a variety of reaction pathways other than cyclometalation has been optimized to achieve metallacycles, especially oxidative addition involving $\mathrm{C}-\mathrm{X}$ bond activation ( $\mathrm{X}=\mathrm{F}, \mathrm{Cl}, \mathrm{Br}, \mathrm{I}$, etc. $)$ and transmetalation. Similarly, metallacycles may be generated by elimination reactions, by cycloaddition and by hydrometalation.

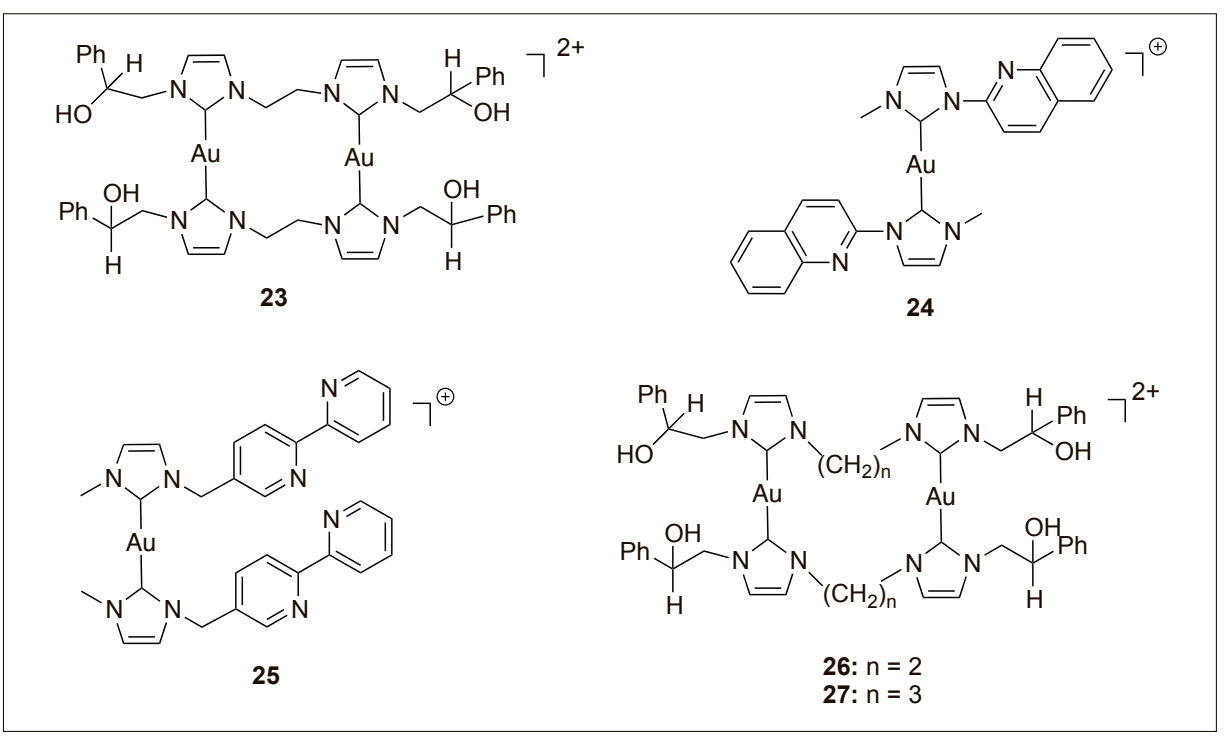

Fig. 6. Antimalarial $\mathrm{Au}(\mathrm{I})$ and $\mathrm{Au}(\mathrm{III})$ complexes with $\mathrm{N}$-heterocyclic carbenes.

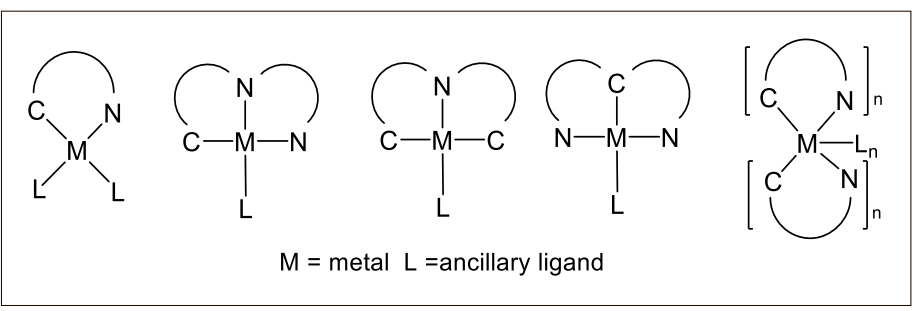

Fig. 7 illustrates a general representation of the different classes of cyclometalated $\mathrm{Au}(\mathrm{III})$ compounds.

In the following sections, $\mathrm{C}^{\wedge} \mathrm{N}$ $\mathrm{C}^{\wedge} \mathrm{N}^{\wedge} \mathrm{N}$ and $\mathrm{C}^{\wedge} \mathrm{N}^{\wedge} \mathrm{C}$ cyclometalated $\mathrm{Au}(\mathrm{III})$ complexes will be discussed, and several studies report on their stability in physiological environment and suitable chemicophysical properties for therapeutic applications. We have decided to organize this section according to the different families, and within each section we will then summarize and highlight the compounds' biological properties and possible applications, mainly as anticancer agents.

\subsection{C^N Complexes}

The class of $\mathrm{Au}(\mathrm{III}) \mathrm{C}^{\wedge} \mathrm{N}$ complexes with cytotoxic properties was first introduced by Parish et al. in 1996, ${ }^{[48]}$ when a series of $\mathrm{Au}$ (III) complexes of the structure [(damp) $\mathrm{AuX}_{2}$ ] with a 2[dimethylamino) methyl]-phenyl (damp) backbone (28) was synthesized and characterized (Fig. 8). The compounds displayed cytotoxic activities comparable to cisplatin against various cancer cell lines, with the malonato- and acetato-substituted complex being the most selective and active of the series in vitro, and showing moderate anticancer effects in vivo. Interestingly, while only minor interactions of the compounds with DNA could be observed, both complexes led to submicromolar inhibition of cysteine protease cathepsin $\mathrm{B}^{[49]}$ as well as inhibition of TrxR.[50]

In 2005, Messori et al. reported on the synthesis of complex 29 featuring a dimethybenzyl-pyridine backbone (Fig. 8). ${ }^{[51]}$ This complex proved to be stable under intercellular reducing conditions; although the cytotoxic activity against ovarian cancer cell line A2780 is comparable to cisplatin, complex 29 displays significant cross-resistance, suggesting a different mechanism of action. It was demonstrated that 29 selectively inhibits TrxR activity, which is hypothesized to be caused by binding to (seleno)cysteine residues in the active site of TrxR. ${ }^{[52]}$ Further studies showed that the hydrolysis product of $\mathbf{2 9}$ is able to disrupt mitochondrial function and alter the glycolytic pathway in A2780 cancer cells, leading to apoptosis. ${ }^{[53]}$

The cationic complex 30, bearing a bisguanide moiety, was synthesized by Che et al. in 2012 (Fig. 8). ${ }^{[54]}$ By introducing the polar bisguanide ligand, a watersoluble complex was obtained that can form an $\mathrm{Au}(\mathrm{III})-\mathrm{GSH}$ complex detectable by ESI-MS. The complex displays higher toxicity than cisplatin against several cancer cell lines, such as cervical cancer (HeLa) cells. The toxicity of complex $\mathbf{3 0}$ is likely to be caused by swelling of the endoplasmic reticulum (ER), as suggested 
by oligonucleotide microarray analysis and western blot assays. Irreversible ER stress triggers apoptosis, with the activation of the canonical mitochondrial cell death pathway playing an essential role.[55] A structural analogue (31) was reported by the same group, also utilizing a dimethybenzyl-pyridine $\mathrm{C}^{\wedge} \mathrm{N}$ backbone and a dithiocarbamate ligand. ${ }^{[56]}$ This complex selectively inhibits breast cancer cells (MCF-7) but is less toxic to nontumorigenic immortalized liver cells (MIHA). Complex 31 was demonstrated to form adducts with cysteine-containing peptides and proteins (e.g. deubiquitinases) by ESI-MS experiments. Notably, Au(III) $\mathrm{C}^{\wedge} \mathrm{N}$ complexes bearing a dithiocarbamate ligand had been previously demonstrated by Contel et al. to cause mitochondrial dysfunction induced by reactive oxygen species (ROS) and Bax/Bak activation. [57]

Synthesis of the 2-benzylpyridine derivative 32 (Fig. 8) was reported by Cinellu et al. ${ }^{[58]}$ already in 1996 by reacting $\mathrm{NaHAuCl}_{4}$ with 2-benzylpyridine in refluxing $\mathrm{MeCN} / \mathrm{H}_{2} \mathrm{O}$ overnight. In 2015 Casini, Cinellu et al. synthesized the structural analogue by replacing one chlorido ligand in the presence of excess $\mathrm{KPF}_{6}$ with $1,3,5$ triaza-7-phosphaadamantane (PTA). ${ }^{[59]}$ The cytotoxic properties of complex 32 and $\mathbf{3 3}$ against various cancer cell lines such as ovarian adenocarcinoma (A2780), mammary carcinoma (MCF-7) and lung carcinoma (A549) were explored. Both complexes demonstrate good cytotoxic activity, with complex $\mathbf{3 3}$ displaying higher cytotoxic activity than $\mathbf{3 2}$, which can probably be attributed to the increased water solubility induced by the PTA moiety, as well as the overall positive charge of the complex. Among the possible mechanism of actions, potent inhibition of the zinc-finger protein PARP-1 was reported, which has been already demonstrated for several coordination gold(III) complexes with N-donor ligands. [60]

\subsection{C^N^N Complexes}

In 2003, Cinellu and coworkers reported on the synthesis of the mononuclear $\mathrm{Au}(\mathrm{III})$ complex 34 with a dimethylbenzylbipyridine $\mathrm{C}^{\wedge} \mathrm{N}^{\wedge} \mathrm{N}$ backbone (Fig. 9). ${ }^{[61]} \mathrm{By}$ choosing a $\mathrm{OH}^{-}$ligand in ancillary position to the $\mathrm{Au}$ (III) center, good solubility of the complex under physiological conditions was obtained. Upon reaction with the plasma protein bovine serum albumin (BSA), tight metal-protein adducts were formed. It is believed that binding of complex 34 to BSA is achieved via histidine moieties on the protein surface. Complex 34 shows higher cytotoxic activity and selectivity against a series of 12 human tumor cell lines than cisplatin, and inhibition of biologically relevant pathways, such as mammalian target of rapamycin/rapamycin

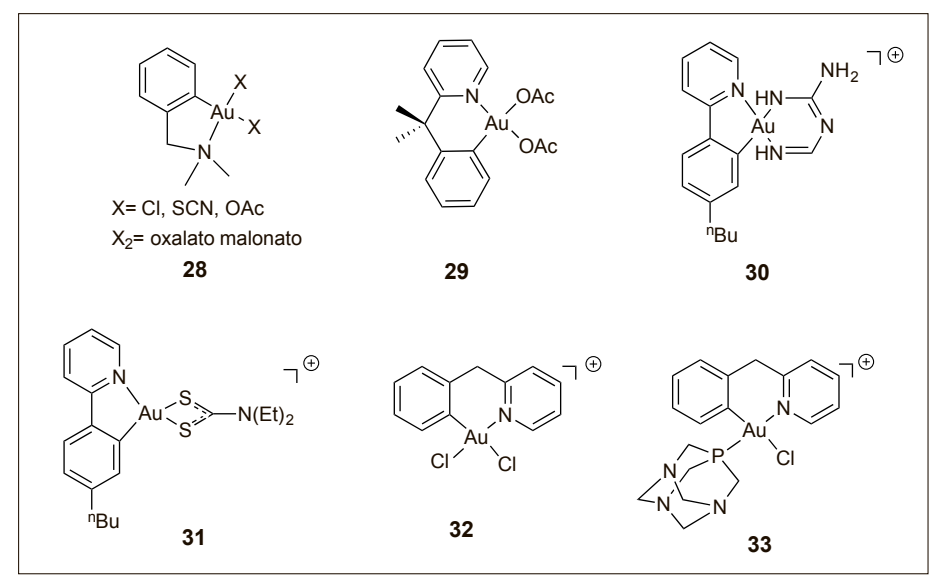

Fig. 8. $A u(I I) C^{\wedge} N$ complexes with cytotoxic properties.

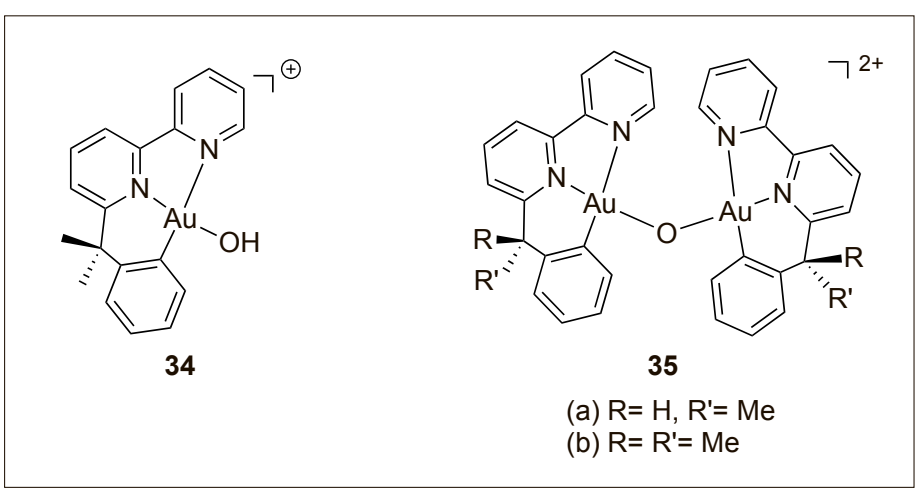

Fig. 9. Mononuclear and dinuclear Au(III) $\mathrm{C}^{\wedge} \mathrm{N}^{\wedge} \mathrm{N}$ complexes.

(mTOR), have been suggested as a possible mechanism of action. ${ }^{[62]}$

Following the above-mentioned trend of designing multinuclear complexes, the same group reported on the dinuclear, oxo-bridged complex variants of general formula $\left[\left(\mathrm{N}^{\wedge} \mathrm{N}^{\wedge} \mathrm{C}\right){ }_{2} \mathrm{Au}_{2}(\mu-\mathrm{O})\right]\left[\mathrm{PF}_{6}\right]_{2}$ (Fig. 9) and their cytotoxic properties in 2011. [61] Coordination oxo-bridged Au(III) $\mathrm{N}^{\wedge} \mathrm{N}$ complexes had been previously reported [63] ('Auoxo' compounds) showing antiproliferative effects toward various human cancer cell lines. However, the latter compounds displayed the scarce stability of the $\mathrm{Au}(\mathrm{III})$ center in the reducing intercellular milieu, which was overcome by introducing the strong $\mathrm{Au}-\mathrm{C}$ bond in the organometallic analogues. Notably, the latter reveal a marked redox stability even in the presence of effective biological reductants such as ascorbic acid and glutathione. In comparison to complex 34, complexes 35a-b showed in general rather moderate cytotoxic activity against the series of 12 human tumor cell lines. However, 35a proved to be particularly active against human breast cancer cells (401NL), while 35b displayed only scarcely selective cytotoxic activity. Mass spectrometry studies with model proteins (hen egg white lysozyme and horse heart cytochrome c) indicate that complexes 35a-b form monometallic adducts with the proteins, preserving the $\mathrm{Au}(\mathrm{III})$ center and retaining the multidentate ligand. It appears that the complex-protein interaction facilitates the cleavage of the oxo-bridge and conversion into the more reactive monometallic species.

\section{4 $C^{\wedge} N^{\wedge} C$ Complexes}

$\mathrm{Au}(\mathrm{III}) \mathrm{C}^{\wedge} \mathrm{N}^{\wedge} \mathrm{C}$ complexes with anticancer properties have been explored by Che and coworkers (Fig. 10). As $\mathrm{C}^{\wedge} \mathrm{N}^{\wedge} \mathrm{C}$ pincer ligands allow the highest stabilization of the Au(III) center among the herewith presented ligands, it is not surprising that this family makes up the majority of the reported cyclometalated $\mathrm{Au}(\mathrm{III})$ compounds.

The Au(III) complex class utilizing the 2,6-diphenylpyridine as a $\mathrm{C}^{\wedge} \mathrm{N}^{\wedge} \mathrm{C}$ ligand was reported by Che et al. already in 1998[64] via reaction of $\mathrm{K}\left[\mathrm{AuCl}_{4}\right]$ and $\left[\mathrm{Hg}\left(\mathrm{C}^{\wedge} \mathrm{N}^{\wedge} \mathrm{CH}\right) \mathrm{Cl}\right]$ under reflux in $\mathrm{MeCN}$. Substitution of the chlorido ligand of complex 36 leads to a number of cationic $\mathrm{Au}(\mathrm{III})-\mathrm{C}^{\wedge} \mathrm{N}^{\wedge} \mathrm{C}$ complexes with different ancillary ligands (37-40). Complex 37 and 38, containing non-toxic N-donor ligands, display cytotoxic activities similar to cisplatin against various cancer cell lines, such as HeLa cancer cells. ${ }^{[65]}$ However, they do not show cross-resistance with cisplatin against nasopharyngeal (NPC) cancer cells. Gel-mobility shift assays and viscosity analysis show that $\mathbf{3 7}$ intercalates with DNA, causing DNA elongation. It has been reported that DNA intercalators enhance the assembly 
of G-quadruplexes. Consequently, the ability of compound $\mathbf{3 7}$ to intercalate with DNA and induce the formation of intramolecular G-quadruplexes from a model oligonucleotide, was examined by native polyacrylamide gel electrophoresis (PAGE), ${ }^{65]}$ showing that 37 behaves similarly to the classical DNA intercalator $[\mathrm{Pt}(\text { terpy }) \mathrm{Cl}]^{+}$and could potentially cause telomerase inhibition. In addition, by flow cytometry analysis in SUNE1 cells, it was demonstrated that $\mathbf{3 7}$ and $\mathbf{3 8}$ target cellular DNA via S-phase cell arrest, leading to apoptosis.

As observed in several studies, phosphine-containing compounds exhibit ligand-mediated cytotoxicity, ${ }^{[5,66]}$ which, in addition to their poor stability under physiological conditions and non-specific binding affinities towards various biomolecules, prevent their application as anticancer drugs. By introducing the $\mathrm{C}^{\wedge} \mathrm{N}^{\wedge} \mathrm{C}$ scaffold, significantly higher complex stabilities were obtained. For example, complex 39 and its dinuclear analogue 40 are soluble and stable in aqueous media. ${ }^{[65]}$ The dinuclear complexes of type 40 show higher antiproliferative activity against various cancer cell lines than their mononuclear counterparts, especially for $\mathrm{n}=3$, relating to the cytotoxicity of the free 1,2-bis(diphenylphosphino)propane (dppp) ligand. In vivo studies in rats with liver cancer (HCC) orthografts showed that the dppp derivative is a nanomolar inhibitor of TrxR1 and induces ER stress, while being scarcely reactive with DNA.[67]

By replacing the $\mathrm{PPh}_{3}$ moiety with a NHC ligand, complexes $\mathbf{4 1}$ and $\mathbf{4 2}$ - monoand dinuclear compounds, respectively can be obtained, ${ }^{[68]}$ resulting in the reduction of the cytotoxic activity and selectivity of the compounds, supporting the fact that indeed phosphine ligand-mediated cytotoxicity is crucial for complexes $\mathbf{3 9}$ and 40. In this case, the mononuclear complex 41 displays higher cytotoxic activity than its dinuclear analogue $\mathbf{4 2}$, being 167-fold more cytotoxic to non-small lung carcinoma cells (NCI-H460) than to normal lung fibroblast cells (CCD-19Lu). DNA interaction studies showed that complex 41 induces DNA strand breaks and subsequent cell death through the stabilization of TopoI-linked DNA.[69]

Interestingly, a recent development in the field of $\mathrm{Au}(\mathrm{III}) \mathrm{C}^{\wedge} \mathrm{N}^{\wedge} \mathrm{C}$ complexes is the discovery of supramolecular polymers, self-assembled from cyclometalated Au(III) $\mathrm{C}^{\wedge} \mathrm{N}^{\wedge} \mathrm{C}$ complexes. In this framework, the mononuclear complex $[\mathrm{Au}(\mathrm{C}, \mathrm{N}, \mathrm{C})$ $(4-d p t)]^{+} \quad(4-d p t=2,4-$ diamino-6- $(4-$ pyridyl)-1,3,5-triazine) $\mathbf{4 3}$ (Fig. 10) was chosen by Che et al. due to the ability of the antiangiogenic 4-dpt ligand to form intramolecular hydrogen bonds and to establish $\pi-\pi$ interactions. ${ }^{[70]}$

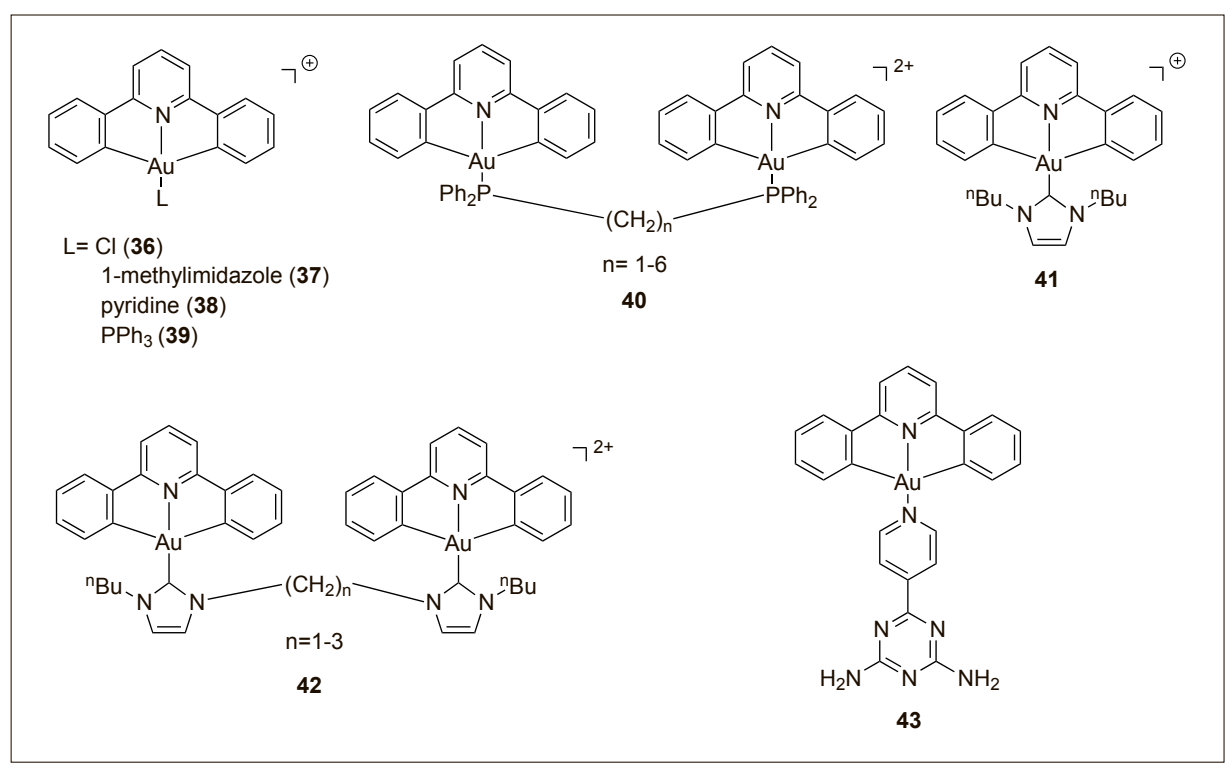

Fig. 10. $\mathrm{Au}(\mathrm{III}) \mathrm{C}^{\wedge} \mathrm{N}^{\wedge} \mathrm{C}$ complexes synthesized by Che et al. ${ }^{[70]}$ with different types of ancillary ligands.

Via transmission electron (TEM) and scanning electron microscopy (SEM), partially aligned nanofibers with diameters and lengths of about $50 \mathrm{~nm}$ could be demonstrated for 43. Complex 43 displays high cytotoxic activity towards murine cancer cell line B16 and non-tumorigenic lung fibroblast cells (CCD-19Lu). It was suggested that the sustained release of free 4-dpt ligand and simultaneous formation of $\mathrm{Au}(\mathrm{III})$-glutathione adducts account for the observed cytotoxicity. GSH adduct formation was assessed via ESI-MS and UV-VIS for 43 in phosphate-buffered saline containing GSH ( $2 \mathrm{mM})$, showing significant cluster peaks for $\left[\left(\mathrm{C}^{\wedge} \mathrm{N}^{\wedge} \mathrm{C}\right)\right.$ $\mathrm{Au}(\mathrm{GSH})]^{+}$and the dimeric species $\left[\left(\mathrm{C}^{\wedge} \mathrm{N}^{\wedge} \mathrm{C}\right)_{2} \mathrm{Au}_{2}(\mathrm{GSH})_{2}\right]^{2+}$. Furthermore, the nanofiber network of the polymer could be used to encapsulate other cytotoxic agents, thus enabling a localized drug delivery while reducing side toxicity.

\section{Conclusions and Perspectives}

Nowadays, gold compounds constitute an important class of promising cytotoxic agents which could be optimized to target cancer cells, provided that adequate attention in disclosing the effective cellular and molecular mechanisms through which these compounds induce their antiproliferative effects will be dedicated. So far, a number of studies has shown that the redox metabolism and mitochondria are the likely cellular targets for several metal-based inorganic compounds, capable of inducing oxidative stress, such as the above-mentioned goldbased complexes. Within this framework, the selenoprotein thioredoxin reductase, playing a crucial role in maintaining the intracellular redox homeostasis, constitutes a major pharmacological target for gold compounds, with high affinity for protein selenol and thiol groups. Indeed, it is recognized that TrxR inhibition by gold compounds triggers severe mitochondrial deregulation eventually leading to cell apoptosis.

Certainly, physiological targets other than TrxR should be studied in more detail for organometallic gold complexes in the future. For example, therapeutically relevant zinc finger (ZF) proteins have recently been reported to be potently targeted by classical coordination metal compounds, including $\mathrm{Au}(\mathrm{I})$ and $\mathrm{Au}(\mathrm{III})$ complexes.[60a] While $\mathrm{Au}(\mathrm{I}) \mathrm{NHC}$ complexes were revealed to be only moderate inhibitors of these proteins, ${ }^{[27]}$ cyclometallated $\mathrm{Au}(\mathrm{III})$ compounds may be better candidates. It is worth mentioning that the hypothesized mechanism of inhibition displacement of $\mathrm{Zn}^{2+}$ from the ZF peptide by gold ions leads to decreased protein activity, and to formation of the so-called 'gold-finger' (GF) domain. ${ }^{[71]}$ So far, the reported results suggest that GF formation by $\mathrm{Au}(\mathrm{III})$ complexes leads to the strongest alteration of the native ZF structure responsible for protein inactivation.

Moreover, among the most intriguing protein targets for coordination $\mathrm{Au}(\mathrm{III})$ complexes, the aquaporins (AQPs) have been recently highlighted. ${ }^{[72]}$ AQPs are membrane channels that facilitate the permeation of water and small solutes across membranes, driven by osmotic or solute gradients, with numerous roles in physiology. In fact, AQPs are essential proteins involved in crucial metabolic processes and expressed in several tissues. Most importantly, their selective inhibition by either small compounds or biologicals 
constitute a realistic opportunity for therapeutic applications and/or methods for diagnosis and treatment of aquaporin related disorders, including cancer. ${ }^{[73]}$

In terms of possible chemical modifications, the use of carboxylic acid and alkyne functionalized $\mathrm{Au}(\mathrm{I})-\mathrm{NHC}$ complexes for biomolecule conjugation is promising to develop organometallic gold scaffolds for biomedical applications. Similarly, the opportunity to derivatize the complexes with groups increasing their water solubility (e.g. $\mathrm{COOH}, \mathrm{OH}$, sugars, etc.) is worth exploring, although this may also limit their cellular uptake.

In general, exploration of the cellular uptake, subcellular distribution, as well as the fate of these metallodrugs (monoor poly-nuclear) inside cells is of major importance to gain insight into their mechanism of action. Thus, there is an increasing need for imaging methods that allow the direct mapping of the subcellular distribution of metal-based therapeutics, while preserving important morphological information of the cell. The fluorescence properties with which certain metal complexes are endowed are certainly attractive to achieve their imaging in biological environments. ${ }^{[74]}$ As an example, cytotoxic $\mathrm{Au}(\mathrm{I})-\mathrm{NHC}$ complexes bearing a fluorescent anthracenyl ligand[75] or $\mathrm{Au}(\mathrm{I})-\mathrm{NHC}[76]$ compounds bound to a coumarin moiety were designed and successfully studied for their cell uptake via fluorescence microscopy. Concerning fluorescent cyclometalated $\mathrm{Au}(\mathrm{III})$ complexes, some of the above mentioned complexes are endowed with peculiar photophysical properties.

Finally, there are still several very interesting cyclometalated $\mathrm{Au}(\mathrm{III})$ complexes reported in the literature, such as highly luminescent $\mathrm{Au}(\mathrm{III}) \quad \mathrm{C}^{\wedge} \mathrm{N}^{\wedge} \mathrm{C}$ complexes bearing a pyrazine moiety, ${ }^{[77]}$ that are only applied in catalysis and have not been tested for their anticancer properties. It would be highly interesting to try to exploit them also for biological applications, for example as cytotoxic agents acting via a catalytic mechanism in cancer cells.

In general, we are convinced that organometallic gold complexes hold great promise for the development of novel therapeutic agents and are worth exploring.

\section{Acknowledgements}

The authors thank Cardiff University and Technische Universität München (TUM) graduate school for funding. A.C. acknowledges the Hans Fischer Senior Fellowship of the TUM - Institute for Advanced Study, funded by the German Excellence Initiative and the European Union Seventh Framework Programme under grant agreement $\mathrm{n}^{\circ} 291763$.

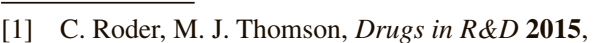
15, 13.

[2] M. Patra, G. Gasser, N. Metzler-Nolte, Dalton Trans. 2012, 41, 6350.

[3] A. R. Sannella, A. Casini, C. Gabbiani, L. Messori, A. R. Bilia, F. F. Vincieri, G. Majori, C. Severini, FEBS Lett. 2008, 582, 844.

[4] M. Mphahlele, M. Papathanasopoulos, M. A. Cinellu, M. Coyanis, S. Mosebi, T. Traut, R. Modise, J. Coates, R. Hewer, Bioorg. Med. Chem. 2012, 20, 401.

[5] S. Nobili, E. Mini, I. Landini, C. Gabbiani, A Casini, L. Messori, Med. Res. Rev. 2010, 30, 550.

[6] S. J. Berners-Price, P. J. Barnard, Ligand Des. Med. Inorg. Chem. 2014, 227.

[7] a) A. Casini, L. Messori, Curr. Topics Med. Chem. 2011, 11, 2647; b) K. P. Bhabak, B. J. Bhuyan, G. Mugesh, Dalton Trans. 2011, 40, 2099.

[8] L. Messori, F. Abbate, G. Marcon, P. Orioli, M. Fontani, E. Mini, T. Mazzei, S. Carotti, T. O'Connell, P. Zanello, J. Med. Chem. 2000, 43, 3541 .

[9] a) E. Vergara, E. Cerrada, A. Casini, O. Zava, M. Laguna, P. J. Dyson, Organometallics 2010 29, 2596; b) E. Schuh, S. M. Valiahdi, M. A. Jakupec, B. K. Keppler, P. Chiba, F. Mohr, Dalton Trans. 2009, 10841; c) A. Meyer, C. P. Bagowski, M. Kokoschka, M. Stefanopoulou, H. Alborzinia, S. Can, D. H. Vlecken, W. S. Sheldrick, S. Wölfl, I. Ott, Angew. Chem. Int Ed. 2012, 51, 8895; d) D. Zhang, Z. Xu, J. Yuan, Y.-X. Zhao, Z.-Y. Qiao, Y.-J. Gao, G.-A Yu, J. Li, H. Wang, J. Med. Chem. 2014, 57, 8132; e) J. Arcau, V. Andermark, E. Aguiló, A Gandioso, A. Moro, M. Cetina, J. C. Lima, K. Rissanen, I. Ott, L. Rodríguez, Dalton Trans. 2014, 43, 4426; f) V. Andermark, I. Ott, J. Biol. Inorg. Chem. 2014, 19, S791.

[10] E. García-Moreno, A. Tomás, E. Atrián-Blasco, S. Gascón, E. Romanos, M. J. Rodriguez-Yoldi, E. Cerrada, M. Laguna, Dalton Trans. 2016, 45, 2462.

[11] W. Liu, R. Gust, Coord. Chem. Rev. 2016, 329, 191

[12] a) G. Gasser, I. Ott, N. Metzler-Nolte, J. Med. Chem. 2011, 54, 3; b) B. Bertrand, A. Casini, Dalton Trans. 2014, 43, 4209.

[13] M. Albrecht, Chem. Rev. 2010, 110, 576.

[14] B. Bertrand, L. Stefan, M. Pirrotta, D. Monchaud, E. Bodio, P. Richard, P. Le Gendre, E. Warmerdam, M. H. de Jager, G. M. Groothuis, M. Picquet, A. Casini, Inorg. Chem. 2014, 53, 2296.

[15] S. J. Berners-Price, A. Filipovska, Metallomics 2011, 3, 863 .

[16] M. Matsui, M. Oshima, H. Oshima, K. Takaku, T. Maruyama, J. Yodoi, M. M. Taketo, Develop. Biol. 1996, 178, 179.

[17] D. Mustacich, G. Powis, Biochem. J. 2000 $346,1$.

[18] B. W. Lennon, C. H. Williams, Biochem. 1997, 36, 9464.

[19] S. Gromer, J. Wissing, D. Behne, K. Ashman, R. H. Schirmer, L. Flohe, K. Becker, Biochem. J. 1998, 332, 591 .

[20] A. Bindoli, M. P. Rigobello, G. Scutari, C. Gabbiani, A. Casini, L. Messori, Coord. Chem. Rev. 2009, 253, 1692.

[21] C. H. Lillig, A. Holmgren, Antioxidants \& Redox Signaling 2007, 9, 25.

[22] a) M. Berggren, A. Gallegos, J. R. Gasdaska, P. Y. Gasdaska, J. Warneke, G. Powis, Anticancer Res. 1995, 16, 3459; b) H. Nakamura, J. Bai, Y. Nishinaka, S. Ueda, T. Sasada, G. Ohshio, M. Imamura, A. Takabayashi, Y. Yamaoka, J. Yodoi, Cancer Detect. Prev. 1999, 24, 53.

[23] a) E. S. Arner, A. Holmgren, in 'Seminars in Cancer Biology', vol. 16, Elsevier, 2006, pp. 420-426; b) S. Urig, K. Becker, in 'Seminars in Cancer Biology', vol. 16, Elsevier, 2006, pp. 452-465.

[24] M. V. Baker, P. J. Barnard, S. J. Berners-Price, S. K. Brayshaw, J. L. Hickey, B. W. Skelton, A. H. White, Dalton Trans. 2006, 3708.

[25] T. V. Serebryanskaya, A. A. Zolotarev, I. Ott, MedChemComm 2015, 6, 1186.

[26] M. Pellei, V. Gandin, M. Marinelli, A. Orsetti, F. Del Bello, C. Santini, C. Marzano, Dalton Trans. 2015, 44, 21041.

[27] B. Bertrand, L. Stefan, M. Pirrotta, D. Monchaud, E. Bodio, P. Richard, P. Le Gendre, E. Warmerdam, M. H. de Jager, G. M. Groothuis, Inorg. Chem. 2014, 53, 2296.

[28] C. Bazzicalupi, M. Ferraroni, F. Papi, L. Massai, B. Bertrand, L. Messori, P. Gratteri, A. Casini, Angew. Chem. Int. Ed. 2016, 55, 4256.

[29] N. Farrell, Chem. Soc. Rev. 2015, 44, 8773.

[30] B. Bertrand, E. Bodio, P. Richard, M. Picquet, P. Le Gendre, A. Casini, J. Organometallic Chem. 2015, 775, 124

[31] B. Bertrand, A. Citta, I. L. Franken, M. Picquet, A. Folda, V. Scalcon, M. P. Rigobello, P. Le Gendre, A. Casini, E. Bodio, J. Biol. Inorg. Chem. 2015, 20, 1005.

[32] A. B. Mullick, Y. M. Chang, I. Ghiviriga, K. A. Abboud, W. Tan, A. S. Veige, Dalton Trans. 2013, 42, 7440

[33] T. Zou, C. T. Lum, C.-N. Lok, W.-P. To, K.-H Low, C.-M. Che, Angew. Chem. Int. Ed. 2014, 53,5810 .

[34] J. Fernández-Gallardo, B. T. Elie, M. Sanaú, M. Contel, Chem. Commun. 2016, 52, 3155.

[35] L. Boselli, M. 1. Carraz, S. Mazères, L. Paloque, G. n. González, F. o. Benoit-Vical, A. Valentin, C. Hemmert, H. Gornitzka, Organometallics 2015, 34, 1046 .

[36] J. K. Muenzner, B. Biersack, A. Albrecht, T. Rehm, U. Lacher, W. Milius, A. Casini, J. J. Zhang, I. Ott, V. Brabec, Chem. Eur. J. 2016, ??, ???.

[37] J. C. Garrison, W. J. Youngs, Chem. Rev. 2005, $105,3978$.

[38] a) K. M. Hindi, M. J. Panzner, C. A. Tessier, C. L. Cannon, W. J. Youngs, Chem. Rev. 2009, 109, 3859; b) İ. Özdemir, A. Denizci, H. T. Öztürk, B. Cetinkaya, Appl. Organometallic Chem. 2004, 18, 318 .

[39] S. Ray, R. Mohan, J. K. Singh, M. K. Samantaray, M. M. Shaikh, D. Panda, P. Ghosh, J. Am. Chem. Soc. 2007, 129, 15042.

[40] a) İ.. Özdemir, N. Temelli, S. Günal, S. Demir, Molecules 2010, 15, 2203; b) R. R. Butorac, S. S. Al-Deyab, A. H. Cowley, Molecules 2011, 16, 2285.

[41] G. Roymahapatra, S. M Mandal, W. F Porto, T. Samanta, S. Giri, J. Dinda, O. L Franco, P. K Chattaraj, Curr. Med. Chem. 2012, 19, 4184.

[42] C. Schmidt, B. Karge, R. Misgeld, A. Prokop, R. Franke, M. Brönstrup, I. Ott, Chem. Eur. J. 2016, ??, ???

[43] C. Biot, W. Castro, C. Y. Botté, M. Navarro, Dalton Trans. 2012, 41, 6335.

[44] World Health Organization, 'Eliminating Malaria', Geneva, 2016.

[45] B. D. Glisic, M. I. Djuran, Dalton Trans. 2014 43,5950 .

[46] J. Coetzee, S. Cronje, L. Dobrzańska, H. G. Raubenheimer, G. Jooné, M. J. Nell, H. C. Hoppe, Dalton Trans. 2011, 40, 1471.

[47] C. Hemmert, A. Fabié, A. Fabre, F. BenoitVical, H. Gornitzka, Eur. J. Med. Chem. 2013, 60,64 .

[48] R. G. Buckley, A. M. Elsome, S. P. Fricker, G. R. Henderson, B. R. Theobald, R. V. Parish, B. P. Howe, L. R. Kelland, J. Med. Chem. 1996, 39, 5208.

[49] S. P. Fricker, R. M. Mosi, B. R. Cameron, I Baird, Y. Zhu, V. Anastassov, J. Cox, P. S. Doyle, E. Hansell, G. Lau, J. Langille, M. Olsen, L. Qin, R. Skerlj, R. S. Y. Wong, Z. Santucci, J. H. McKerrow, J. Inorg. Biochem. 2008, 102, 1839. 
[50] L. Engmann, M. McNaughton, M. Gajewska, S. Kumar, A. Birmingham, G. Powis, Anticancer Drugs 2006, 17, 539.

[51] M. Coronnello, E. Mini, B. Caciagli, M. A. Cinellu, A. Bindoli, C. Gabbiani, L. Messori, $J$. Med. Chem. 2005, 48, 6761.

[52] T. Zou, C. T. Lum, C.-N. Lok, J.-J. Zhang, C.M. Che, Chem. Soc. Rev. 2015, 44, 8786.

[53] T. Gamberi, L. Massai, F. Magherini, I. Landini, T. Fiaschi, F. Scaletti, C. Gabbiani, L. Bianchi, L. Bini, S. Nobili, G. Perrone, E. Mini, L. Messori, A. Modesti, J. Proteomics 2014, 103 , 103.

[54] J.-J. Zhang, R. W.-Y. Sun, C.-M. Che, Chem. Commun. 2012, 48, 3388.

[55] H. Urra, C. Hetz, Cell Death Differ. 2012, 19, 1893.

[56] C.-M. Che, R. W.-Y. Sun, Chem. Commun. 2011, 47, 9554.

[57] N. Shaik, A. Martínez, I. Augustin, H. Giovinazzo, A. Varela-Ramírez, M. Sanaú, R. J. Aguilera, M. Contel, Inorg. Chem. 2009, 48, 1577.

[58] M. A. Cinellu, A. Zucca, S. Stoccoro, G. Minghetti, M. Manassero, M. Sansoni, J. Chem. Soc., Dalton Trans. 1996, 4217.

[59] B. Bertrand, S. Spreckelmeyer, E. Bodio, F Cocco, M. Picquet, P. Richard, P. Le Gendre, C. Orvig, M. A. Cinellu, A. Casini, Dalton Trans. 2015, 44, 11911 .

[60] a) F. Mendes, M. Groessl, A. A. Nazarov, Y. O. Tsybin, G. Sava, I. Santos, P. J. Dyson,
A. Casini, J. Med. Chem. 2011, 54, 2196; b) Y. Zhu, B. R. Cameron, R. Mosi, V. Anastassov, J. Cox, L. Qin, Z. Santucci, M. Metz, R. T. Skerlj, S. P. Fricker, J. Inorg. Biochem. 2011, 105, 754.

[61] C. Gabbiani, A. Casini, G. Kelter, F. Cocco, M. A. Cinellu, H. H. Fiebig, L. Messori, Metallomics 2011, 3, 1318.

[62] A. Casini, G. Kelter, C. Gabbiani, M. A. Cinellu, G. Minghetti, D. Fregona, H.-H. Fiebig, L. Messori, J. Biol. Inorg. Chem. 2009, 14, 1139.

[63] A. Casini, M. A. Cinellu, G. Minghetti, C. Gabbiani, M. Coronnello, E. Mini, L. Messori, J. Med. Chem. 2006, 49, 5524.

[64] K.-H. Wong, K.-K. Cheung, M. C.-W. Chan, C.M. Che, Organometallics 1998, 17, 3505.

[65] C. K. L. Li, R. W. Y. Sun, S. C. F. Kui, N. Zhu, C. M. Che, Chem. Eur. J. 2006, 12, 5253.

[66] S. Berners-Price, P. Sadler, Chemistry in Britain 1987, 23, 541.

[67] S. Castelli, O. Vassallo, P. Katkar, C.-M. Che, R. W.-Y. Sun, A. Desideri, Arch. Biochem. Biophys. 2011, 516, 108.

[68] J. J. Yan, A. L.-F. Chow, C.-H. Leung, R. W.Y. Sun, D.-L. Ma, C.-M. Che, Chem. Commun. 2010, 46, 3893.

[69] R. Wai-Yin Sun, D.-L. Ma, E. L.-M. Wong, C.M. Che, Dalton Trans. 2007, 4884.

[70] J. J. Zhang, W. Lu, R. W. Y. Sun, C. M. Che, Angew. Chem. Int. Ed. 2012, 51, 4882.

[71] Ü. Laskay, C. Garino, Y. Tsybin, L. Salassa, A. Casini, Chem. Commun. 2015, 51, 1612
[72] a) G. Soveral, S. Nielsen, A. Casini, 'Aquaporins in Health and Disease: New Molecular Targets for Drug Discovery', CRC Press, 2016; b) A. de Almeida, G. Soveral, A. Casini, MedChemComm 2014, 5, 1444; c) A. P. Martins, A. Marrone, A. Ciancetta, A. G. Cobo, M. Echevarría, T. F. Moura, N. Re, A. Casini, G. Soveral, PloS one 2012, 7, e37435.

[73] G. Soveral, A. Casini, Expert Opinion on Therapeutic Patents 2016, 1.

[74] a) E. Bodio, P. Le Gendre, F. Denat, C. Goze, $A d v$. Inorg. Chem. 2016, 68, 253; b) K. Y Zhang, K. K. W. Lo, Inorg. Chem. Biol.: Princ. Techn. Appl. 2014, 99; c) M. P. Coogan, V. Fernández-Moreira, Chem. Commun. 2014, 50, 384; d) R. Kumar, W. S. Shin, K. Sunwoo, W. Y. Kim, S. Koo, S. Bhuniya, J. S. Kim, Chem. Soc. Rev. 2015, 44, 6670 .

[75] A. Citta, E. Schuh, F. Mohr, A. Folda, M. L. Massimino, A. Bindoli, A. Casini, M. P. Rigobello, Metallomics 2013, 5, 1006.

[76] B. Bertrand, A. de Almeida, E. P. van der Burgt, M. Picquet, A. Citta, A. Folda, M. P. Rigobello, P. Le Gendre, E. Bodio, A. Casini, Eur. J. Inorg. Chem. 2014, 4532.

[77] J. Fernandez-Cestau, B. Bertrand, M. Blaya, G. A. Jones, T. J. Penfold, M. Bochmann, Chem. Commun. 2015, 51, 16629. 